\title{
CHINA AND THE LOST WORLDS OF THE DINOSAURIAN ERA
}

RUSSELL, Dale A., Research Div., Canadian Museum of Nature, P.O. Box 3443, Station D, Ottawa, ON K1P 6P4 CANADA

What is known of dinosaurian biogeography suggests a centre of evolution first on a fragmenting Pangea-Gondwana and then on a consolidating Laurasia. By Cretaceous time members of Gondwanan low-latitude abelisaur-titanosaur assemblages often bore "back-fans," while those in polar latitudes were relictual and/or highly derived. The time of last contact between South America and Africa is not well constrained, but links to Antarctica continued beyond the end of the Cretaceous. Many Gondwanan tetrapods appear to have waif-dispersed to Laurasia across southern Europe; few crossed in the opposite direction until the end of the period. Laurasian assemblages were then typically dominated by tyrannosaurids and hadrosaurids.

Land masses ("lost worlds") periodically became isolated from Gondwana-Laurasia. (1) Eastern Asia was isolated between middle Jurassic through Neocomian time, although related temnospondyls and carnosaurs may have co-existed in Austral regions. Mamenchisaurs were the dominant giant terrestrial herbivores, while whip-tailed diplodocids filled the same role in Pangea. Groups of European-North American affinity then replaced many Asian endemics in a manner reminiscent of the Neogene mammalian turnover in South America. (2) In North America, Late Jurassic dinosaur assemblages exhibited Gondwana affinities, but by Late Cretaceous time they were dominated by forms of Asian ancestry. The apparent low diversity of Aptian-Albian dinosaur assemblages and absence of well-marked endemism may have been the result of a brief period of isolation. (3) European archipelagos were a filter bridge between northern lands and Gondwana analogous to the East Indies, which separate comparably different modern biotas in southeast Asia and Australia. (4) During Barremian time India probably hosted an polar dinosaurian assemblage, but low-latitude Gondwana forms (abelisaurids, titanosaurids) were present during at least part of this interval. Isolation ended with the immigration of northern taxa in Maestrichtian time.

Underexplored Mesozoic horizons of great biogeographic interest include (1) the Middle Jurassic-Neocomian of China for microvertebrate materials, (2) the pre-Maestrichtian Cretaceous of India, and (3) the post-Cenomanian of Africa, Australia and Antarctica. Paradoxically, the two recently discovered dinosaurian specimens of the latter age in Antarctica, which represent about as much biogeographic information as all described materials of similar age from Africa combined (none are known from Australia), are presently referred to families with Laurasian distributions. 